\title{
Significance of PRO2000/ANCCA expression, a novel proliferation-associated protein in hepatocellular carcinoma
}

\author{
Jie Yang ${ }^{1 \dagger}$, Jie Huang ${ }^{1 \dagger}$, Luqiao Luo $^{1}$, Zhenzhu Chen ${ }^{1}$, Ying Guo ${ }^{2}$ and Linlang Guo ${ }^{1 *}$
}

\begin{abstract}
Background: PRO2000/ANCCA may be an important candidate gene which located within a region of chromosome $8 \mathrm{q}$ in hepatocellular carcinoma (HCC). However, its significance remains unclear. The aim of this study was to explore the clinical significance of PRO2000/ANCCA expression in HCC.

Methods: The correlations of PRO2000/ANCCA expression with clinicopathological factors and prognosis of HCC patients were analyzed. Expression of PRO2000/ANCCA, ki-67, cyclinD1, p53 and p21 was detected in HCCs from 107 patients along with corresponding non-tumor tissues by immunohistochemistry.

Results: PRO2000/ANCCA expression was present in 66 of 107 (64.94\%) HCC specimens in which 36 of 76 (47.37\%) in well differentiated tumors and 30 of 31 (96.77\%) in poorly differentiated tumors respectively, while 8 (7.48\%) in adjacent non-tumor tissues with scattered positive cells. PRO2000/ANCCA expression was associated with clinicopathological features such as histological differentiation, number of tumor nodules, TNM stage, tumor microsatellite, portal vein tumor thrombus and recurrence, but not with gender, age, tumor size, cirrhosis, HBV infection and serum fetoprotein (AFP) level. There was a close relationship between PRO2000/ANCCA and ki-67 and cyclinD1 in HCC. PRO2000/ANCCA immunopositivity was independent of p53 and p21 WAF1/Cip1.
\end{abstract}

Conclusions: Increased expression of PRO2000/ANCCA is associated with adverse outcome in patients with HCC and is a predictor of poor prognosis for HCC. PRO2000/ANCCA may be involved in the development of HCC and might promote cell proliferation through a p53/ P21 WAF1/Cip1-independent pathway.

Keywords: PRO2000/ANCCA, Proliferation, Hepatocellular carcinoma (HCC), Immunohistochemistry

\section{Introduction}

Primary hepatocellular carcinoma (HCC), is the fifth most common cancer worldwide and the third most common cause of cancer-related mortality with approximately 696,000 deaths each year. More than $50 \%$ of the worldwide cases of HCC occur in China, because of the high prevalence of chronic hepatitis B virus infection and liver cirrhosis $[1,2]$. A detailed understanding of the molecular mechanisms associated with HCC ultimately could improve our current diagnosis and treatments for this disease. Throughout the years, many important advances have been made to understand the pathogenesis of $\mathrm{HCC}$.

\footnotetext{
* Correspondence: linlangg@yahoo.com

${ }^{\dagger}$ Equal contributors

'Department of Pathology, Zhujiang Hospital, Southern Medical University,

Guangzhou, China
}

Full list of author information is available at the end of the article
A subset of cytogenetic changes, including frequent gain of chromosome 8q which the most commonly amplified region in multiple cancer types were found to be involved in the early development of HCC by comparative genomic hybridization $(\mathrm{CGH})$ and comparative genomic microarray analysis (CGMA). PRO2000/ANCCA, one of the genes on chromosome $8 \mathrm{q}$ was highly expressed (4.7 folds) in HCC comparing to corresponding non-cancerous samples and showed a high correlation between DNA copy number and expression levels in HCC samples. The data suggested that PRO2000/ANCCA may be an important candidate gene in the development of HCC [3].

PRO2000, a novel member of the AAA + superfamily, has been also named as ANCCA (AAA nuclear coregulator cancer-associated protein) or ATAD2 (AAA domain containing 2) or TAAB (ACTR target with AAA + ATPase 
and bromodomain) in the NCBI protein database [4]. ANCCA and ATAD2 are the most commonly used names in the published data, but we prefer to call it PRO2000, which is the originate name of this gene first discovered in HCC. PRO2000/ANCCA contains two AAA + domains in the central region with the first one being crucial for its transcription coactivator function and a bromodomain close to the $\mathrm{COOH}$-terminus that specifically recognizes acetylated histones [5]. Several laboratories have reported that PRO2000/ANCCA was overexpressed in different human cancers, including breast cancer, prostate cancer, lung cancer and endometrial cancer. High levels of PRO2000/ANCCA was associated with poor prognosis in cancer patients. These studies showed PRO2000/ ANCCA was involved in the estrogen and androgen receptor pathways to mediate estrogen- or androgeninduced expression of specific subsets of proliferationassociated genes. In addition, PRO2000/ANCCA acts as an important co-regulator of $\mathrm{MYC}$ and contributes to the development of aggressive cancer [6-13]. However, the molecular mechanisms of PRO2000/ANCCA leading to hepatocarcinogenesis and progression are still not clearly understood.

In this study, we investigated for the first time the significance of PRO2000/ANCCA expression in HCC. Protein expression of PRO2000/ANCCA was examined in relation to clinicopathological features in 107 cases of HCC by immunohistochemical technique. The relationships between PRO2000/ANCCA expression and ki-67, cyclin D1, p53 and p21 ${ }^{\text {WAF1/Cip1 }}$ were also analyzed in the present study.

\section{Materials and methods}

\section{Tissue preparation}

One hundred and seven samples were obtained by surgical resection in our department between January 2004 and June 2008. The patients, 96 males (89.7\%) and $11 \mathrm{fe}-$ males $(10.3 \%)$, ranged in age from 30 to 79 years (mean 51.45). Tumor sizes were divided as less than or equal to $5 \mathrm{~cm}(\mathrm{n}=55)$ and more than $5 \mathrm{~cm}(\mathrm{n}=52)$. Tumor stage was defined according to the 7th edition of the American Joint Committee on Cancer staging manual. Written informed consent was obtained from all the patients for the use of the tumor tissues for clinical research and the publication of this report. The project protocol was approved by the Institutional Ethics Committee of Zhujiang Hospital prior to the initiation of the study. Clinicopathological features of study population were presented in Table 1. All samples were independently reviewed by two pathologists. The cases of HCC were classified according to the criteria described by Edmondso-Steiner and grouped as well differentiated (gradeI-II; $\mathrm{n}=76$ ) or poorly differentiated (grade III-IV; $\mathrm{n}=31$ ). All 107 specimens contained pericarcinomatous tissues, in which including 56
Table 1 Clinicopathological correlation of PRO2000/ ANCCA expression in HCC

\begin{tabular}{|c|c|c|c|c|c|}
\hline \multirow{2}{*}{ Feature } & \multirow{2}{*}{ Cases } & \multicolumn{3}{|c|}{ PRO2000/ANCCA } & \multirow[t]{2}{*}{$P$-value } \\
\hline & & - & + & ++ & \\
\hline Gender & & & & & 0.697 \\
\hline Male & 96 & 38 & 46 & 12 & \\
\hline Female & 11 & 3 & 6 & 2 & \\
\hline Age (years) & & & & & 0.524 \\
\hline$\leq 51$ & 53 & 23 & 23 & 7 & \\
\hline$>51$ & 54 & 18 & 29 & 7 & \\
\hline Serum HBsAg & & & & & 0.737 \\
\hline Negative & 44 & 17 & 20 & 7 & \\
\hline Positive & 63 & 24 & 32 & 7 & \\
\hline Serum AFP (ng/ml) & & & & & 0.703 \\
\hline$\leq 20$ & 48 & 18 & 25 & 5 & \\
\hline$>20$ & 59 & 23 & 27 & 9 & \\
\hline Tumor size $(\mathrm{cm})$ & & & & & 0.107 \\
\hline$\leq 5$ & 55 & 25 & 26 & 4 & \\
\hline$>5$ & 52 & 16 & 26 & 10 & \\
\hline Tumor number & & & & & 0.003 \\
\hline Single & 80 & 38 & 32 & 10 & \\
\hline Multiple & 27 & 3 & 20 & 4 & \\
\hline Tumor differentiation & & & & & $<0.001$ \\
\hline$|-| \mid$ & 76 & 40 & 34 & 2 & \\
\hline III-IV & 31 & 1 & 18 & 12 & \\
\hline Cirrhosis & & & & & 0.519 \\
\hline Negative & 51 & 21 & 22 & 8 & \\
\hline Positive & 56 & 20 & 30 & 6 & \\
\hline TNM stage & & & & & $<0.001$ \\
\hline$|-| \mid$ & 81 & 41 & 38 & 2 & \\
\hline III-IV & 26 & 0 & 14 & 12 & \\
\hline Tumor microsatellite & & & & & 0.011 \\
\hline Absent & 77 & 36 & 31 & 10 & \\
\hline Present & 30 & 5 & 21 & 4 & \\
\hline $\begin{array}{l}\text { Portal vein tumor } \\
\text { thrombus }\end{array}$ & & & & & $<0.001$ \\
\hline Absent & 96 & 41 & 47 & 8 & \\
\hline Present & 11 & 0 & 5 & 6 & \\
\hline Recurrence & & & & & $<0.001$ \\
\hline Absent & 89 & 39 & 43 & 7 & \\
\hline Present & 18 & 2 & 9 & 7 & \\
\hline
\end{tabular}

- , negative; + , moderate positive; ++ , strong positive. Significant differences are shown in bold.

cases with cirrhosis. Sixty-three patients were seropositive for $\mathrm{HBsAg}$ and $\mathrm{HBeAg}$. No positive case for $\mathrm{HCV}$ was present in this study. All tissues were fixed in $10 \%$ formalin ( $\mathrm{pH}$ 7.0) for 12-24 hours and embedded in 


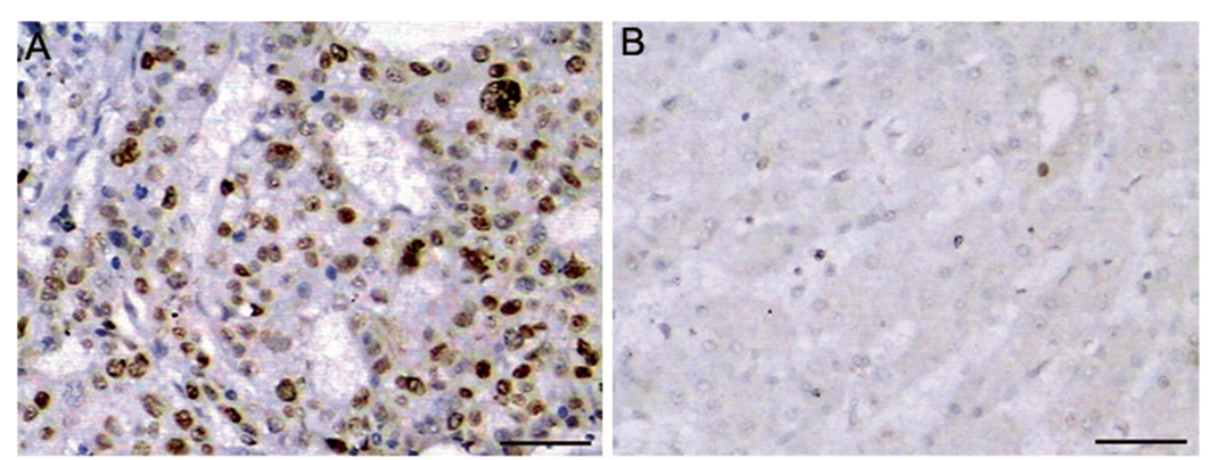

Figure 1 Immunohistochemical staining of PRO2000/ANCCA protein in human liver tissue samples. (A) HCC tissues and (B) adjacent non-tumor tissues were immunohistochemically stained with an anti-PRO2000/ANCCA antibody Positive PRO2000/ANCCA immunostaining was mainly localized in the nucleus of cells. Scale bars $=50 \mu \mathrm{m}$.

paraffin wax and then $4 \mu \mathrm{m}$ serial sections were cut and mounted on poly-l-lysine coated slides.

\section{Immunohistochemical staining}

Sections were deparaffinized and rehydrated routinely. Before adding the primary antibody, antigen was retrieved by heating sections in $10 \mathrm{mM}$ citrate buffer (pH 6.0) in a microwave oven for 10 minutes followed by 10 minutes of cooling. After blocking with $0.3 \% \mathrm{H}_{2} \mathrm{O}_{2}$ and goat serum, the slides were then incubated with a primary antibody, directed against PRO2000/ANCCA (1:100 dilution, gift from Dr Hongwu Chen's lab, UCDAVIS, Cancer center, USA), ki-67(MIB-1, Dako, Glostrup, Denmark), cyclin D1(SP4, Dako, Glostrup, Denmark), p53(DO-7, Dako, Glostrup, Denmark) and p21 ${ }^{\mathrm{WAF} 1 / \mathrm{Cip} 1}$ (4D10, Dako, Glostrup, Denmark) at $4^{\circ} \mathrm{C}$ overnight. Biotinylated secondary antibodies were then applied according to the manufacturer's recommendations (Amersham). After incubation with avidin biotin complex using the Vector Elite $\mathrm{ABC}$ detection kit (Vector Labs, Burlingame, USA), reaction products were visualized by 3 'diaminobenzidine (DAB), and slides were subsequently counterstained with hematoxylin. Brown-yellow granules in nucleus or cytoplasm were considered positive staining. The positive reactivity was scored semiquantitatively by microscopic evaluation according to the estimated number of positive nuclei or cytoplasm of target cells. The scores were graded into four groups from 0 to $3+$ as follow : 0 , no positive cells; + , less than $25 \%$ of positive cells; $2+$, $25-50 \%$ of positive cells; and $3+,>50 \%$ of positive cells. Negative controls were performed by replacing the primary antibodies stated above with PBS. The specimens were classified according to IHC staining scores of PRO2000/ANCCA as negative group $(-, n=41)$, moderate positive group $(+, \mathrm{n}=52)$, strong positive group $(++, \mathrm{n}=14)$.

\section{Statistical analysis}

Correlation of PRO2000/ANCCA expression with clinical features, and expression of ki-67, cyclin D1, p53 and $\mathrm{p} 21^{\text {WAF1/Cip } 1}$ was calculated by $\chi^{2}$ test. Survival curves were obtained by Kaplan-Meier analysis. In all cases, a $P$ value $<0.05$ was considered to indicate statistical significance. Statistical analysis was performed using the SPSS software program 17.0 (SPSS Inc., Chicago, IL, USA).
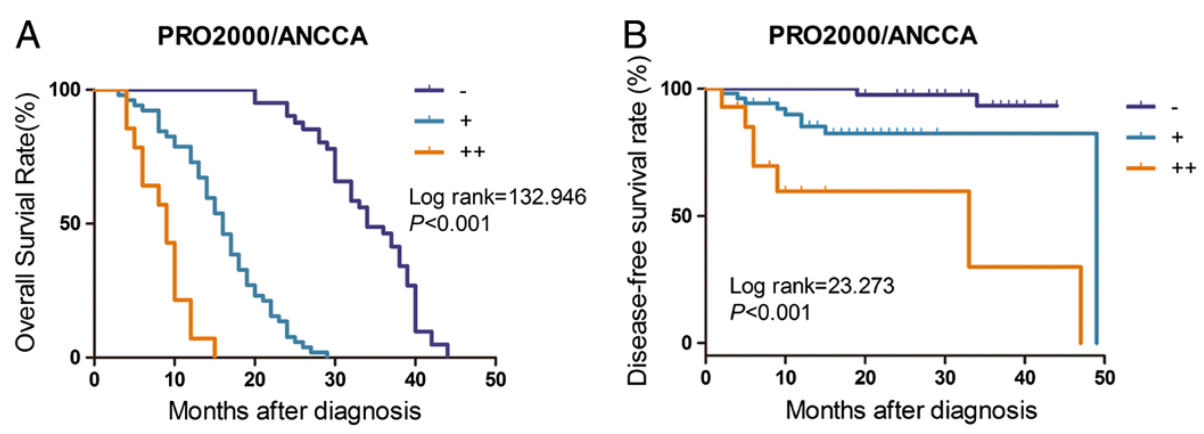

Figure 2 Kaplan-Meier analyses of overall survival (A) and disease-free survival (B) in 107 HCC patients based on PRO2000/ANCCA expression. -, negative; +, moderate positive; ++ , strong positive. 
Table 2 Univariate and multivariate analyses of potential prognostic factors associated with overall survival of HCC patients

\begin{tabular}{|c|c|c|c|c|}
\hline \multirow[t]{2}{*}{ Variables } & \multicolumn{2}{|c|}{ Univariate analysis } & \multicolumn{2}{|c|}{ Multivariate analysis } \\
\hline & $\mathrm{HR}(95 \% \mathrm{Cl})$ & $\mathbf{P}$ & $\mathrm{HR}(95 \% \mathrm{Cl})$ & $\mathbf{P}$ \\
\hline Gender (male/female) & $1.128(0.602-2.115)$ & 0.707 & & \\
\hline Age (years) $(\leq 51 />51)$ & $2.305(1.525-3.484)$ & $<0.001$ & $3.570(2.311-5.516)$ & $<0.001$ \\
\hline Serum HBsAg (negative/positive) & $0.822(0.556-1.215)$ & 0.326 & & \\
\hline Serum AFP (ng/ml) $(\leq 20 />20)$ & $0.945(0.645-1.384)$ & 0.772 & & \\
\hline Tumor size $(\mathrm{cm})(\leq 5 />5)$ & $1.410(0.958-2.077)$ & 0.082 & & \\
\hline Tumor number (single/multiple) & $2.250(1.422-3.559)$ & 0.001 & $1.149(0.300-4.403)$ & 0.839 \\
\hline Tumor differentiation (I-II/III-IV) & $7.922(4.739-13.242)$ & $<0.001$ & $3.292(1.563-6.937)$ & 0.002 \\
\hline Cirrhosis (absent/present) & $0.999(0.679-1.471)$ & 0.996 & & \\
\hline TNM stage $(|-||/|||-|| V)$ & $23.349(11.008-49.527)$ & $<0.001$ & $3.848(1.494-9.915)$ & 0.005 \\
\hline Tumor microsatellite (absent/present) & $1.877(1.216-2.896)$ & 0.004 & $1.404(0.392-5.030)$ & 0.602 \\
\hline Portal vein tumor thrombus (absent/present) & $46.801(16.166-135.495)$ & $<0.001$ & $11.741(3.503-39.355)$ & $<0.001$ \\
\hline Recurrence (absent/present) & $2.739(1.628-4.609)$ & $<0.001$ & $1.220(0.645-2.308)$ & 0.541 \\
\hline ANCCA expression $(-/+/++)$ & $10.275(6.440-16.395)$ & $<0.001$ & $8.745(4.936-15.493)$ & $<0.001$ \\
\hline
\end{tabular}

HR: hazard ratio, $\mathrm{Cl}$ confidence interval. The P-value was calculated by Cox proportional hazards model.

\section{Results}

Expression of PRO2000/ANCCA and its correlation with clinicopathological characteristics in HCC

Immunohistochemical staining demonstrated a granular staining pattern of PRO2000/ANCCA in the nucleus of cancer cells (Figure 1A), whereas few scattered positive cells were detected in adjacent non-tumor tissues (Figure 1B). Sixty-six of 107 (61.68\%) HCC specimens were presented positive staining for PRO2000/ANCCA, while 8 (7.48\%) in non-cancer cells. It was positive in 30/31 (96.77\%) poorly differentiated tumors and 36/76 (47.37\%) well differentiated lesions. There was a significantly increased expression of PRO2000/ANCCA in poorly differentiated tumors than that in well differentiated tumors $\left(\chi^{2}=36.736, P<0.001\right)$. The intensity of PRO2000/ANCCA staining in cancer cells was much stronger than that in non-cancer cells.
We further analyzed the relationship between the expression of PRO2000/ANCCA and clinicopathological features of the HCC patients. As shown in Table 1, the expression of PRO2000/ANCCA was showed significant correlation with number of tumor nodules, TNM stage, tumor microsatellite, portal vein tumor thrombus and recurrence. However, no significant relationship was seen between PRO2000/ANCCA expression and gender, age, tumor size, cirrhosis, HBV infection and serum AFP level. In addition, Kaplan-Meier analysis and log-rank test revealed that high expression of PRO2000/ANCCA was significantly associated with shorter overall survival (Figure 2A) and disease-free survival (Figure 2B). Further multivariate Cox regression analysis indicated that PRO2000/ANCCA is an independent prognostic factor for survival of patients with $\mathrm{HCC}(P<0.001$, Table 2$)$.

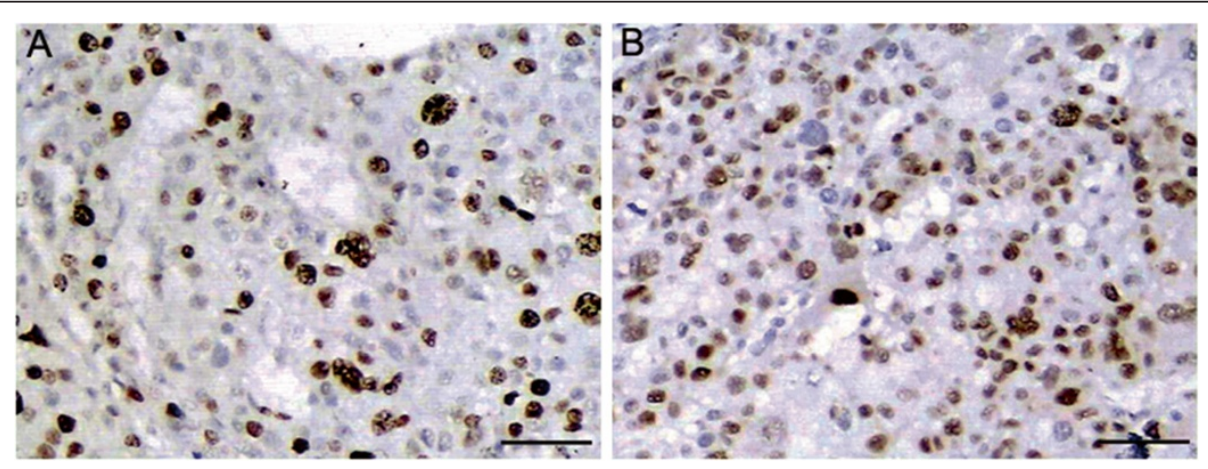

Figure 3 Immunohistochemical expressions of ki-67 and cyclin D1 in consecutive sections of an HCC tissue. Positive immunostaining of (A) ki-67 and (B) cyclinD1 were localized in the nucleus of cancer cell. Scale bars $=50 \mu \mathrm{m}$. 
Table 3 Relationship between PRO2000/ANCCA and ki-67, cyclin D1, p53 and p21 in HCC

\begin{tabular}{|c|c|c|c|c|c|c|c|c|c|}
\hline \multirow{2}{*}{$\begin{array}{l}\text { PRO2000/ } \\
\text { ANCCA }\end{array}$} & \multirow{2}{*}{ Cases } & \multicolumn{2}{|c|}{ ki-67 } & \multicolumn{2}{|c|}{ cyclin D1 } & \multicolumn{2}{|c|}{ p53 } & \multicolumn{2}{|c|}{ p21 } \\
\hline & & + & - & + & - & + & - & + & - \\
\hline Positive & 65 & 46 & 19 & 40 & 25 & 29 & 36 & 26 & 39 \\
\hline Negative & 42 & 18 & 24 & 9 & 33 & 25 & 17 & 13 & 29 \\
\hline$x^{2}$ & & \multicolumn{2}{|c|}{8.270} & \multicolumn{2}{|c|}{16.536} & \multicolumn{2}{|c|}{2.269} & \multicolumn{2}{|c|}{0.902} \\
\hline$P$-value & & \multicolumn{2}{|c|}{0.004} & \multicolumn{2}{|c|}{$<0.001$} & \multicolumn{2}{|c|}{0.132} & \multicolumn{2}{|c|}{0.342} \\
\hline
\end{tabular}

-, negative; +, positive. Significant differences are shown in bold.

\section{Association between PRO2000/ANCCA and ki-67 or cyclin D1 in HCC}

In all 107 cases of $\mathrm{HCC}$, ki-67 and cyclin D1 positive cells were showed brown staining in the nucleus. In consecutive sections of an HCC, PRO2000/ANCCA, Ki-67 and cyclin D1 were showed to be co-expressed in the same cancer cell within individual tumor (Figure 3).

The correlation between PRO2000/ANCCA and ki-67 or cyclin D1 is summarized in Table 3. The ki-67 and cyclin D1 were significantly higher in PRO2000/ANCCA -positive group than that in PRO2000/ANCCA-negative group $(P<0.05)$.

\section{Association between PRO2000/ANCCA and p53 or p21 in HCC}

Previous studies and our results showed nuclear staining for p53 or p21 $1^{\text {WAF1/Cip1 }}$ in HCCs. However, PRO2000/ ANCCA expression was not consistent with p53 or p21 ${ }^{\text {WAF1/Cip1 }}$ in cancer cells in consecutive sections of an HCC (Figure 4). Nuclear immunoreactivity for p53 and p21 was found in 33 (42.86\%) and 37 (48.05\%) HCCs respectively. We analyzed the expression level of PRO2000/ANCCA and p53 and p21 ${ }^{\text {WAF1/Cip1 }}$ expression in HCC. Among PRO2000/ANCCA-positive cases, p53 and $\mathrm{p} 21^{\mathrm{WAF} 1 / \mathrm{Cip} 1}$ were expressed in $72.7 \%$ and $81.8 \%$ in $\mathrm{HCC}$, respectively. In contrast to cases with negative PRO2000/ANCCA, p53 and p21 ${ }^{\mathrm{WAF} 1 / \mathrm{Cip} 1}$ were expressed in $72.4 \%$ and $79.3 \%$ in HCC. PRO2000/ANCCA expression was not significantly correlated with p53 and p21 WAF1/Cip1 (Table 3).

\section{Discussion}

PRO2000/ANCCA which located within a region of chromosome $8 \mathrm{q}$ was firstly reported to be an important candidate gene in HCC [3]. To our knowledge, investigation on biological function of PRO2000/ANCCA in $\mathrm{HCC}$ has not been reported. In this study, we firstly performed immunohistochemisty method to examine PRO2000/ANCCA expression in 107 cases of human HCC along with corresponding non-tumor tissues. The results showed that PRO2000/ANCCA protein was overexpressed in the majority of cancer cells comparing with surrounding hepatocytes. Our data are consistent with the preliminary report by Crawley et al. using comparative genomic microarray analysis. Of 107 HCC specimens, 61.68\% were demonstrated positive staining for PRO2000/ANCCA, while $7.48 \%$ (8/107) in adjacent non-tumor tissues. There was a statistical difference of PRO2000/ANCCA expression in $\mathrm{HCC}$ and that in adjacent non-tumor tissues. The intensity of PRO2000/ANCCA expression in tumor cells was stronger than that in non-tumor cells. This result therefore supports the view that PRO2000/ANCCA may have specific function in malignant differentiation and proliferation of hepatocytes.

Our data also provided new insights regarding the relationship between PRO2000/ANCCA expression and clinicopathological features in HCC. There was a statistical difference of PRO2000/ANCCA expression in well differentiated tumors and that in poorly differentiated tumors $(P<0.05)$. Thus, level of PRO2000/ANCCA expression was significantly correlated with more aggressive tumor features such as number of tumor nodules, portal vein invasion, tumor microsatellite formation and TNM stage. Our study showed that PRO2000/ANCCApositive cases had less survival rate than those in PRO2000/ANCCA-negative cases. These data suggest that
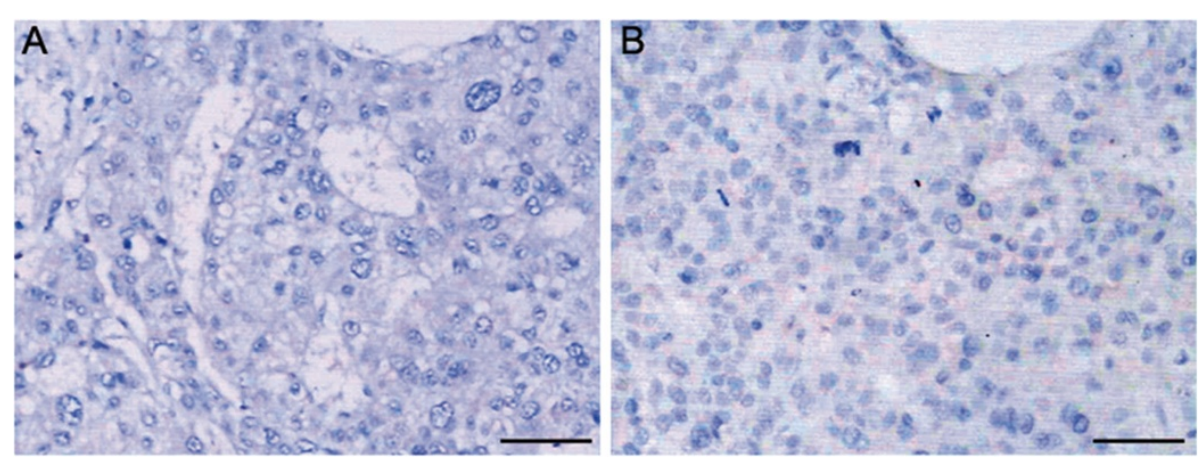

Figure 4 Immunohistochemical staining of P53 and p2 $1^{\text {WAF1/Cip1 }}$ in consecutive sections of an HCC tissue. Tissue sections were immunohistochemically stained with (A) anti-P53 and (B) anti-P21 antibodies. Scale bars $=50 \mu \mathrm{m}$. 
PRO2000/ANCCA in HCC might serve as a valuable predictor for progression and poor prognosis.

PRO2000/ANCCA protein has been reported to be associated directly with estrogen-bound estrogen receptor $\alpha(E R \alpha)$ and to mediate E2-stimulated expression of key cell cycle regulators likely via its ATP-driven protein complex remodeling function in breast cancer [7]. In this study, we observed the expression of PRO2000/ANCCA, $\mathrm{Ki}-67$ and Cyclin D1 in series of sections and found these proteins were expressed in same cancer cell nucleus. Our results showed that PRO2000/ANCCA was strongly positive associated with ki-67 and cyclin D1 in HCC. As a proliferation-associated nuclear antigen, $\mathrm{Ki}-67$ is present in cells that are replicating in the G1, S, G2, and M stages of the cell cycle [14]. Cyclin D1 functions as a regulatory subunit of CDK4 or CDK6, whose activity is required for cell cycle G1/S transition [15]. This finding might support the hypothesis that PRO2000/ANCCA may be involved in the regulation of proliferation in HCC.

The p53 tumor-suppressor gene has been shown to play a key role in the control of the cell cycle, cell differentiation and apoptosis. P21 ${ }^{\mathrm{WAF} 1 / \mathrm{Cip} 1}$, an inhibitor of cyclin-dependent kinases, is activated through p53dependent or p53-independent pathway and plays an important role in regulation of the cell cycle, especially in G1 arrest [15-22]. Many studies have demonstrated that P53 and P21 WAF1/Cip1 are involved in carcinogenesis of hepatocytes [23-25]. According to our results stated above, we are also interested in the relationship between PRO2000/ANCCA and p53 or P21 ${ }^{\mathrm{WAF} 1 / \mathrm{Cip} 1}$. In the present study, PRO2000/ANCCA expression was not consistent with p53 or P21 ${ }^{\mathrm{WAF} 1 / \mathrm{Cip} 1}$ in cancer cells within individual tumor. There was not any correlation between PRO2000/ANCCA and p53 or P21 WAF1/Cip1. These results suggest that PRO2000/ANCCA might promote cell proliferation in HCC through a p53/ $\mathrm{P} 21^{\mathrm{WAF} 1 / \mathrm{Cip} 1}$-independent pathway.

In summary, this study demonstrated that PRO2000/ ANCCA was overexpressed in HCC and was associated with clinicopathological features such as number of tumor nodules, TNM stage, tumor microsatellite, portal vein tumor thrombus and recurrence, but not with gender, age, cirrhosis, HBV infection and serum AFP level. There was a strong positive correlation between PRO2000/ ANCCA expression and ki-67 and cyclin D1 but not p53 and p21. Our findings suggested that PRO2000/ANCCA may be involved in cell cycle regulation in the pathogenesis of $\mathrm{HCC}$ and serves as a predictor for poor prognosis of HCC. PRO2000/ANCCA might be a candidate gene for the development of diagnostic and therapeutic strategies for HCC. Further molecular, cellular and animal model studies are necessary to better understand the function of PRO2000/ANCCA as the present clinical samples study.

\section{Abbreviations}

HCC: Hepatocellular carcinoma; AFP: Alpha fetal protein; ANCCA: AAA nuclear coregulator cancer-associated protein.

\section{Competing interests}

The authors declare that they have no competing interests.

\section{Authors' contributions}

$J Y$ and JH performed clinical data acquisition, statistical analysis and drafted the manuscript. LL and ZC performed immunohistochemical study. YG performed critical revision. LG designed and directed the study. All authors read and approved the final manuscript.

\section{Acknowledgements}

The authors would like to thank the National Natural Science Foundation of China, for financial support (81071987).

\section{Author details}

'Department of Pathology, Zhujiang Hospital, Southern Medical University, Guangzhou, China. ${ }^{2}$ Department of Organ Transplantation, Zhujiang Hospital, Southern Medical University, Guangzhou, China.

Received: 29 November 2013 Accepted: 26 March 2014 Published: 4 April 2014

\section{References}

1. Perry JF, Poustchi H, George J, Farrell GC, MCCaughan GW, Strasser SI: Current approaches to the diagnosis and management of hepatocellular carcinoma. Clin Exp Med 2005, 5(1):1-13.

2. Srivatanakul $P$, Sriplung $H$, Deerasamee $S$ : Epidemiology of liver cancer: an overview. Asian Pac J Cancer Prev 2004, 5(2):118-125.

3. Crawley JJ, Furge KA: Identification of frequent cytogenetic aberrations in hepatocellular carcinoma using gene-expression microarray data. Genome Biol 2002, 3:12. RESEARCH0075.

4. Zou JX, Revenko AS, Li LB, Gemo AT, Chen HW: ANCCA, an estrogen-regulated AAA + ATPase coactivator for ERalpha, is required for coregulator occupancy and chromatin modification. Proc Natl Acad Sci U S A 2007, 104(46):18067-18072.

5. Zou JX, Guo L, Revenko AS, Tepper CG, Gemo AT, Kung HJ, Chen HW: Androgen-induced coactivator ANCCA mediates specific androgen receptor signaling in prostate cancer. Cancer Res 2009, 69(8):3339-3346.

6. Caron C, Lestrat C, Marsal S, Escoffier E, Curtet S, Virolle V, Barbry P, Debernardi A, Brambilla C, Brambilla E, Rousseaux S, Khochbin S: Functional characterization of ATAD2 as a new cancer/testis factor and a predictor of poor prognosis in breast and lung cancers. Oncogene 2010, 29(37):5171-5181.

7. Ciro M, Prosperini E, Quarto M, Grazini U, Walfridsson J, McBlane F, Nucifero P, Pacchiana G, Capra M, Christensen J, Helin K: ATAD2 is a novel cofactor for MYC, overexpressed and amplified in aggressive tumors. Cancer Res 2009, 69(21):8491-8498.

8. Duan Z, Zou JX, Yang P, Wang Y, Borowsky AD, Gao AC, Chen HW: Developmental and androgenic regulation of chromatin regulators $\mathrm{EZH} 2$ and ANCCA/ATAD2 in the prostate Via MLL histone methylase complex. Prostate 2012, 73:455-466.

9. Fouret R, Laffaire J, Hofman P, Beau-Faller M, Mazieres J, Validire P, Girard P, Camilleri-Broet S, Vaylet F, Leroy-Ladurie F, Soria JC, Fouret P: A comparative and integrative approach identifies ATPase family, AAA domain containing 2 as a likely driver of cell proliferation in lung adenocarcinoma. Clin Cancer Res 2012, 18(20):5606-5616.

10. Hsia EY, Kalashnikova EV, Revenko AS, Zou JX, Borowsky AD, Chen HW: Deregulated E2F and the AAA + coregulator ANCCA drive proto-oncogene ACTR/AIB1 overexpression in breast cancer. Mol Cancer Res 2010, 8:183-193.

11. Kalashnikova EV, Revenko AS, Gemo AT, Andrews NP, Tepper CG, Zou JX, Cardiff RD, Borowsky AD, Chen HW: ANCCA/ATAD2 overexpression identifies breast cancer patients with poor prognosis, acting to drive proliferation and survival of triple-negative cells through control of B-Myb and EZH2. Cancer Res 2010, 70(22):9402-9412.

12. Raeder MB, Birkeland E, Trovik J, Krakstad C, Shehata S, Schumacher S, Zack TI Krohn A, Werner HM, Moody SE, Wik E, Stefansson IM, Holst F, Oyan AM, Tamayo P, Mesirov JP, Kalland KH, Akslen LA, Simon R, Beroukhim R, Salvesen HB: Integrated genomic analysis of the 8 q24 amplification in 
endometrial cancers identifies ATAD2 as essential to MYC-dependent cancers. PLoS One 2013, 8(2):e54873.

13. Zhang Y, Sun Y, Li Y, Fang Z, Wang R, Pan Y, Hu H, Luo X, Ye T, Li H, Wang $\mathrm{L}$, Chen $\mathrm{H}$, Ji H: ANCCA Protein Expression is a Novel Independent Poor Prognostic Marker in Surgically Resected Lung Adenocarcinoma. Ann Surg Oncol 2013, 20(Suppl 3):S577-S582.

14. Kaita KD, Pettigrew N, Minuk GY: Hepatic regeneration in humans with various liver disease as assessed by Ki-67 staining of formalin-fixed paraffin-embedded liver tissue. Liver 1997, 17(1):13-16.

15. Gladden AB, Diehl JA: Location, location, location: the role of cyclin D1 nuclear localization in cancer. J Cell Biochem 2005, 96(5):906-913.

16. Aliouat-Denis CM, Dendouga N, Van den Wyngaert I, Goehlmann $H_{\text {, }}$ Steller U, van de Weyer I, Van Slycken N, Andries L, Kass S, Luyten W, Janicot M, Vialard JE: p53-independent regulation of p21Waf1/Cip1 expression and senescence by Chk2. Mol Cancer Res 2005, 3(11):627-634

17. El-Deiry WS, Harper JW, O'Connor PM, Velculescu VE, Canman CE, Jackman J, Pietenpol JA, Burrell M, Hill DE, Wang Y, Wiman KG, Mercer WE, Kastan MB, Kohn KW, Elledge SJ, Kinzler KW, Vogelstein B: WAF1/CIP1 is induced in p53-mediated G1 arrest and apoptosis. Cancer Res 1994, 54(5):1169-1174.

18. El-Deiry WS, Tokino T, Velculescu VE, Levy DB, Parsons R, Trent JM, Lin D, Mercer WE, Kinzler KW, Vogelstein B: WAF1, a potential mediator of p53 tumor suppression. Cell 1993, 75(4):817-825.

19. Harper JW, Adami GR, Wei N, Keyomarsi K, Elledge SJ: The p21 Cdk-interacting protein Cip1 is a potent inhibitor of G1 cyclin-dependent kinases. Cell 1993, 75(4):805-816.

20. Michieli P, Chedid M, Lin D, Pierce JH, Mercer WE, Givol D: Induction of WAF1/ CIP1 by a p53-independent pathway. Cancer Res 1994, 54(13):3391-3395.

21. Noda A, Ning Y, Venable SF, Pereira-Smith OM, Smith JR: Cloning of senescent cell-derived inhibitors of DNA synthesis using an expression screen. Exp Cell Res 1994, 211(1):90-98.

22. Waldman T, Kinzler KW, Vogelstein B: p21 is necessary for the p53-mediated G1 arrest in human cancer cells. Cancer Res 1995, 55(22):5187-5190.

23. Lee TK, Man K, Poon RT, Lo CM, Ng IO, Fan ST: Disruption of p53-p21/ WAF1 cell cycle pathway contributes to progression and worse clinical outcome of hepatocellular carcinoma. Oncol Rep 2004, 12(1):25-31.

24. Qin LF, Ng IO, Fan ST, Ng M: p21/WAF1, p53 and PCNA expression and p53 mutation status in hepatocellular carcinoma. Int I Cancer 1998, 79(4):424-428

25. Su JJ, Ban KC, Li Y, Qin LL, Wang HY, Yang C, Ou C, Duan XX, Lee YL, Yang RQ: Alteration of $\mathrm{p} 53$ and $\mathrm{p} 21$ during hepatocarcinogenesis in tree shrews. World J Gastroenterol 2004, 10(24):3559-3563.

doi:10.1186/1475-2867-14-33

Cite this article as: Yang et al: Significance of PRO2000/ANCCA

expression, a novel proliferation-associated protein in hepatocellular carcinoma. Cancer Cell International 2014 14:33.

\section{Submit your next manuscript to BioMed Central and take full advantage of:}

- Convenient online submission

- Thorough peer review

- No space constraints or color figure charges

- Immediate publication on acceptance

- Inclusion in PubMed, CAS, Scopus and Google Scholar

- Research which is freely available for redistribution 